\title{
EFFECT OF CONCENTRIC AND ECCENTRIC TYPE OF BRACINGS ON PERFORMANCE BASED SEISMIC ANALYSIS OF RC BUILDING
}

\author{
Ziaulla Khan ${ }^{1}$, B.R Narayana ${ }^{2}$, Syed Ahamed Raza ${ }^{3}$ \\ ${ }^{1}$ M.Tech Student of Structural Engineering, Department of Civil Engineering, Ghousia College of Engineering, \\ Karnataka, India \\ ${ }^{2}$ Assistant Professor, Department of Civil Engineering, Ghousia College of Engineering, Karnataka, India \\ ${ }^{3}$ Assistant Professor, Department of Civil Engineering, Ghousia College of Engineering, Karnataka, India
}

\begin{abstract}
When a tall building is subjected to lateral or torsional deflections under the action of seismicloads, the resulting oscillatory movement can induce a wide range of responses in the building's occupants.[1]As a result, lateral stiffness is a major consideration in the design of tall buildings. Bracing is a highly efficient and economical method of resisting lateral forces in a frame structure. In this present study, the effect of four different types of bracing systems have been studied, for the use in SMRF $R C$ framed building situated in seismic zone IV, in order to provide lateral stiffness and results in terms of storey shears and storey drifts have been presented.
\end{abstract}

Keywords: RC Building, Concentric and Eccentric Bracings, Storey Drift,Storey Shear, Pushover Curves.

\section{INTRODUCTION}

Seismic Analysis is a subset of structural analysis and is the calculation of the response of a structure to earthquakes.[5] A reinforced concrete building should be designed to have a capacity to carry combined loads at certain safety level and at certain degree of reliability so, when this design is finally executed in the construction process, the expected performance of the structural building should come into satisfaction. However, this ideal condition is not always realized. Performance of structural building could be below the expected criteria in term of safety level and service life due to a variety of causes. There are several technologies that could be chosen for this purpose such as bracing, shear walls etc[6]

\subsection{Bracing}

A Braced Frame is a structural system which is designed primarily to resist wind and earthquake forces. Members in a braced frame are designed to work in tension and compression, similar to a truss.[2]

\subsection{Types of Bracings}

There are two types of bracing systems

1) Concentric Bracing System and

2) Eccentric Bracing System

1) Concentrically Braced Frames (CBFs) are a class of structures resisting lateral loads through a vertical concentric truss system, the axes of the members aligning concentrically at the joints. Concentric braced frames do not have extensive requirements regarding members or connections, and are frequently used in areas of low seismic risk. Most braced frames are concentric. This means that, where members intersect at a node, the centroid of each member passes through the same point.[3]

2) Eccentrically braced frames (EBFs) are a relatively new lateral force resisting system developed to resist seismic events in a predictable manner. Properly designed and detailed EBFs behave in a ductile manner through shear or flexural yielding of a link element. The link is created through brace eccentricity with either the column centerlines or the beam midpoint. The ductile yielding produces wide, balanced hysteresis loops, indicating excellent energy dissipation, which is required for high seismic events.[7]

\subsection{Objectives}

i. To study the seismic behavior of RC building by performing Linear static and non linear static analysis.

ii. To understand the elastic and plastic behavior of the RC building under gravity loads taken as per IS 875-2000.

iii. Comparitive study for concentrically and eccenctrically placed lateral load resisting systems at different locations.

iv. To compare various parameteric results such as Storey driftand Storey forces for the different models considered.

v. To obtain pushover curves both in $\mathrm{X}$ and $\mathrm{Y}$ directions using FEM based analytical software ETABS 9.7.4.

\subsection{Methodology}

1) Linear Static analysis

2) Non Linear Static analysis 


\subsubsection{Linear Static Analysis}

Linear static analysis defines a way to represent the effect of earthquake ground motion when series of forces are act on a building, through a seismic design response spectrum. This method assumes that the building responds in its fundamental mode. The applicability of this method is extended in many building codes by applying factors to account for higher buildings with some higher modes, and for low levels of twisting. This method is the simplest one and it requires less computational effort and is based on formulae given in the code of practice. First the design base shear is computed for the whole building, and it is then distributed along the height of the building. The lateral forces at each floor level are distributed to individual lateral load resisting element.[8]

\subsubsection{Non Linear Static Analysis}

The pushover analysis of a structure is a static non-linear analysis under permanent vertical loads and gradually increasing lateral loads. The load is incrementally increased in accordance to a certain predefined pattern. The analysis is carried out up to failure, thus it enables determination of collapse load and ductility capacity. On a building frame, plastic rotation is monitored, and a plot of the total base shear versus top displacement in a structure is obtained by this analysis that would indicate any premature failure or weakness. [9]

\section{INTRODUCTION TO BUILDING}

\section{STRUCTURE}

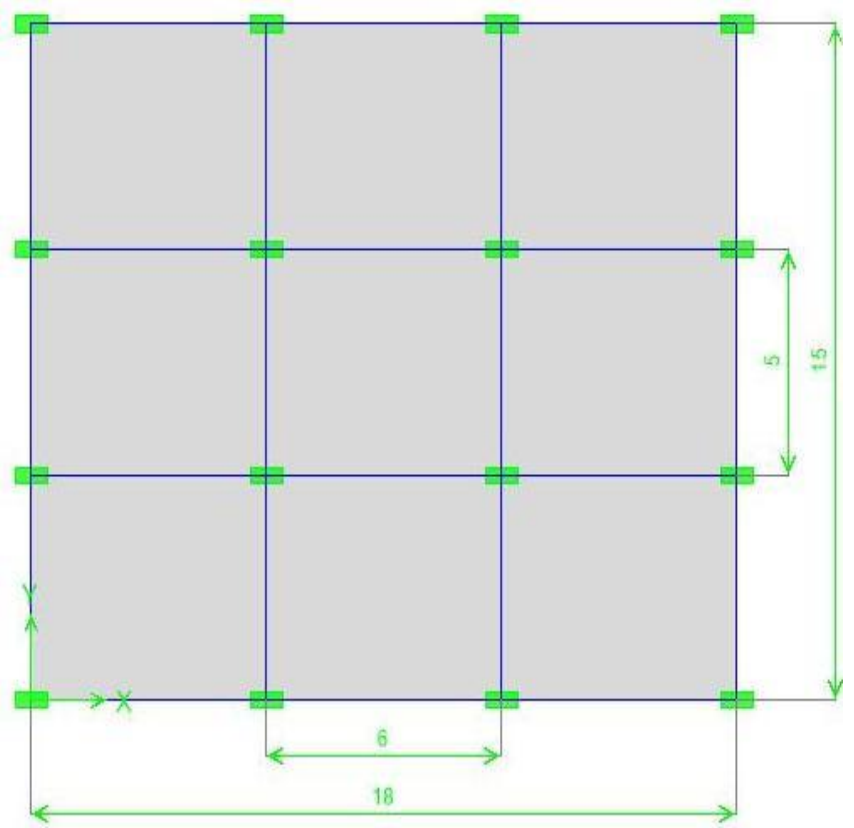

Fig 1: Building plan

Table 1: Model data of Building

\begin{tabular}{|l|l|}
\hline Structure & SMRF \\
\hline No of Stories & G+14 \\
\hline Storey Height & $3 \mathrm{~m}$ \\
\hline
\end{tabular}

\begin{tabular}{|l|l|}
\hline Base Storey & $3.6 \mathrm{~m}$ \\
\hline Type of Soil & Medium Soil \\
\hline Seismic Zone & 4 \\
\hline Importance factor & 1 \\
\hline Material Property & M25 \\
\hline Grade of Concrete & Fe415 \\
\hline Grade of Steel & $300 \times 450 \mathrm{~mm}$ \\
\hline Member Properties & $350 \times 800 \mathrm{~mm}$ \\
\hline Beam Size & $200 \times 200 \mathrm{~mm}$ \\
\hline Column Size & $150 \mathrm{~mm}$ \\
\hline Bracing Size & $2.5 \mathrm{KN} / \mathrm{m}^{2}$ \\
\hline Thickness of Slab & $2 \mathrm{KN} / \mathrm{m}^{2}$ \\
\hline Live Load & $1 \mathrm{KN} / \mathrm{m}^{2}$ \\
\hline Live Load on Roof &
\end{tabular}

\section{STRUCTURE CONSIDERED FOR ANALYSIS}

Model 1: Building has been modeled as a Bare Frame. Model 2: Building has Concentric X bracing at the Center bay.

Model 3: Building has Eccentric $X$ bracing at the Center bay.

Model 4: Building has Concentric Inverted V bracing at the adjacent bay.

Model 5: Building has Eccentric Inverted V bracing at the adjacent bay.

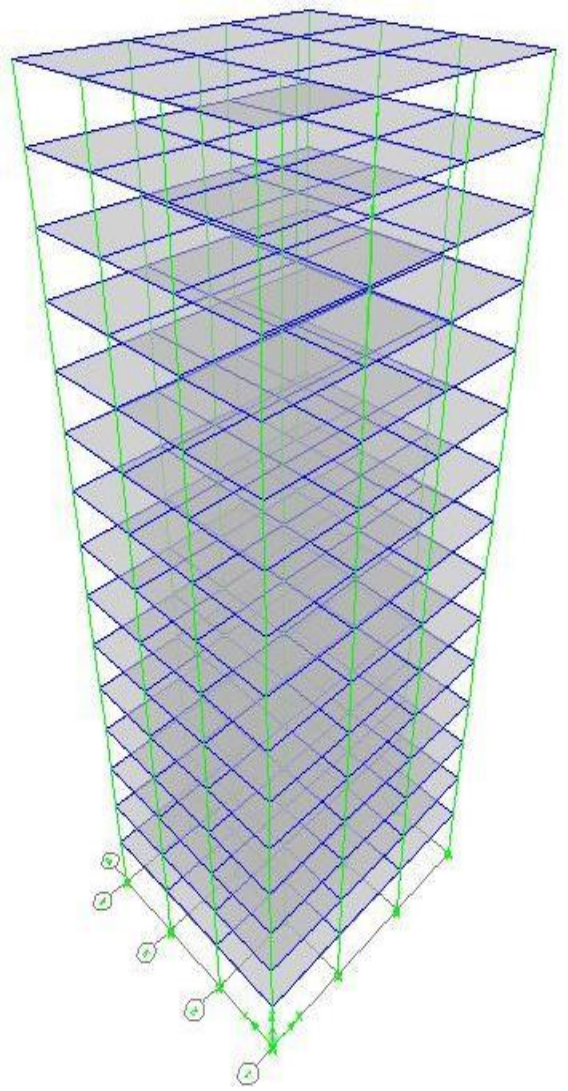

Fig 2: Model 1 


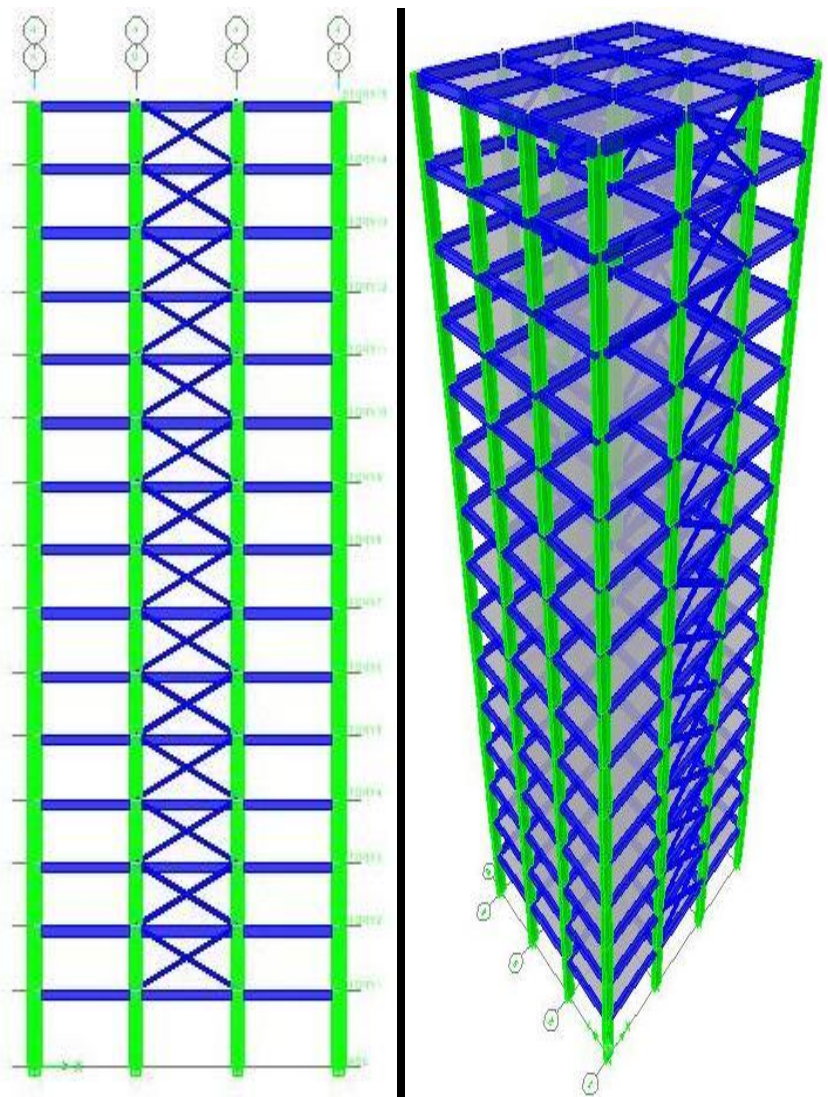

Fig 3: Model 2

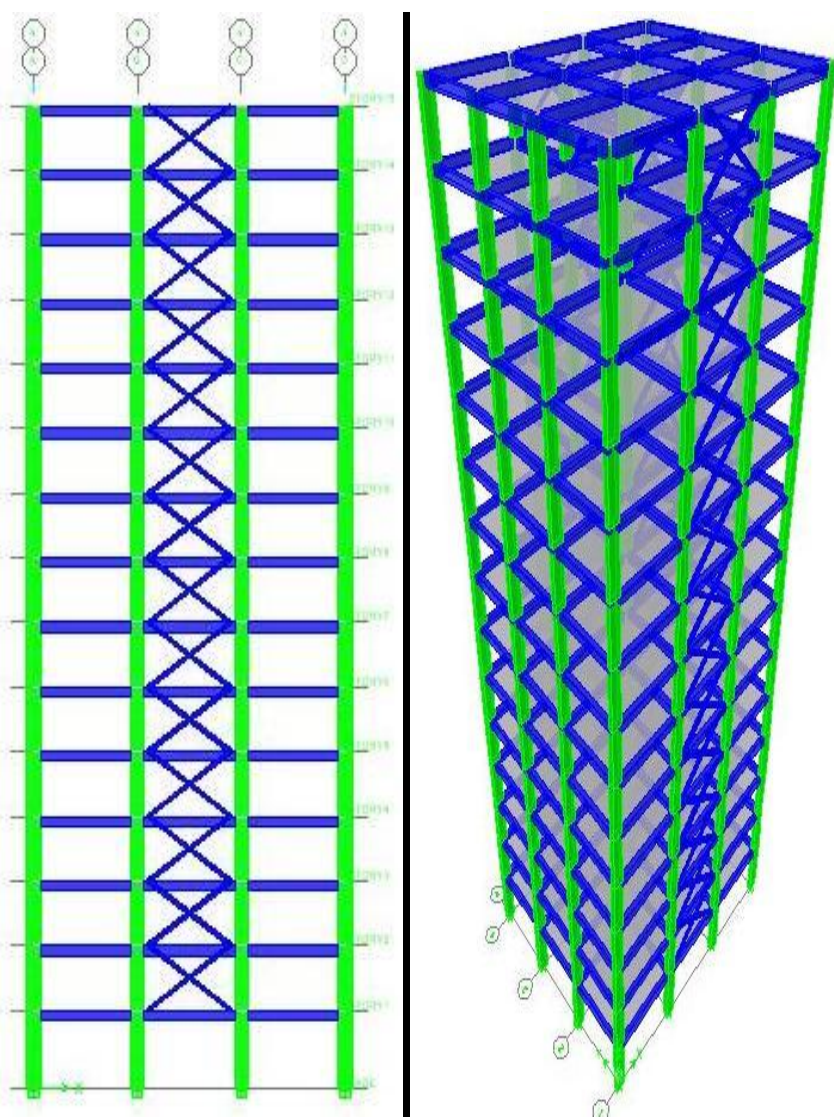

Fig 4: Model 3

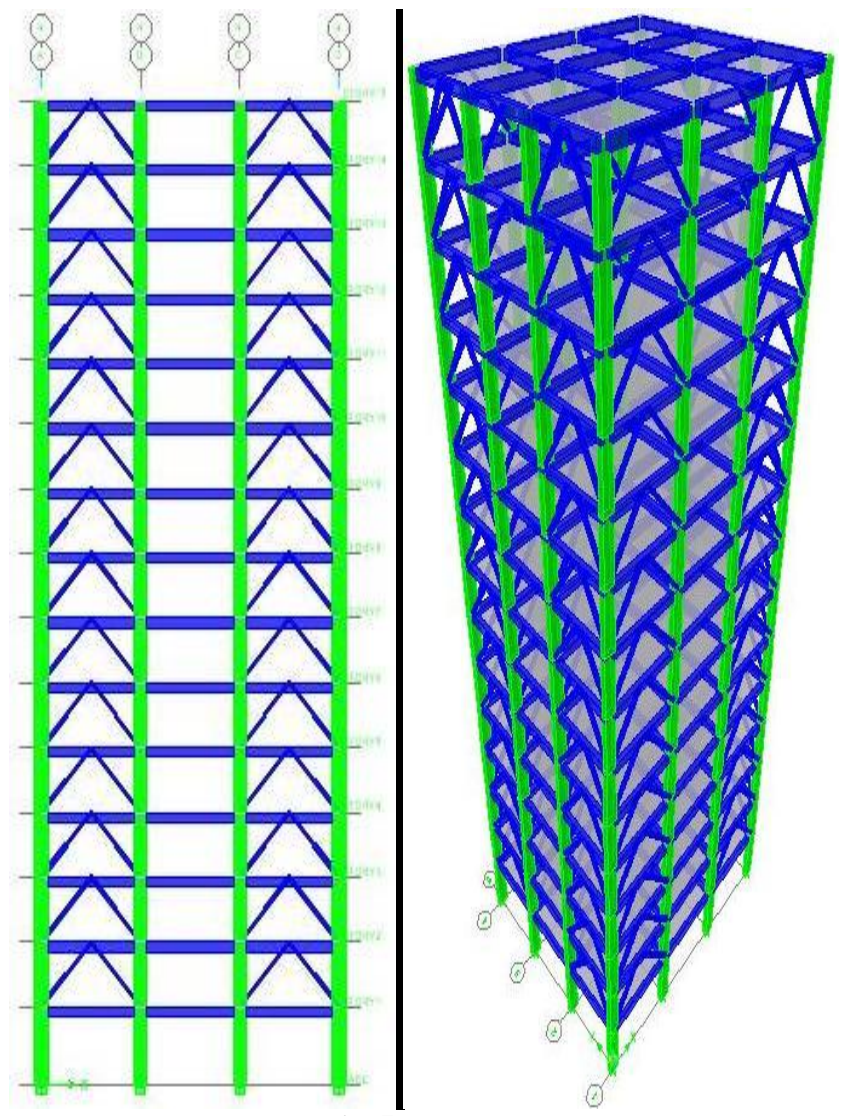

Fig 5: Model 4

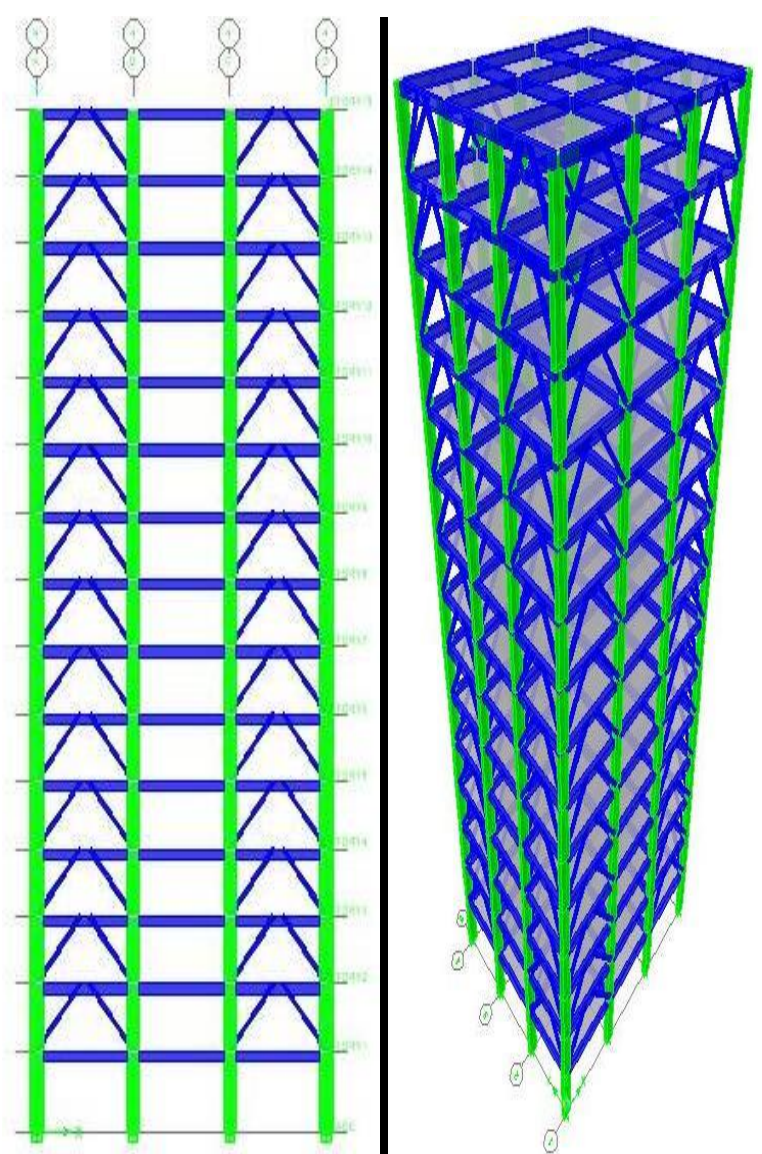

Fig 6: Model 5 


\section{RESULTS}

\subsection{Storey Shear}

Following chart 1 shows storey shear for linear and non linear static analysis in longitudinal $\mathrm{X}$ direction.

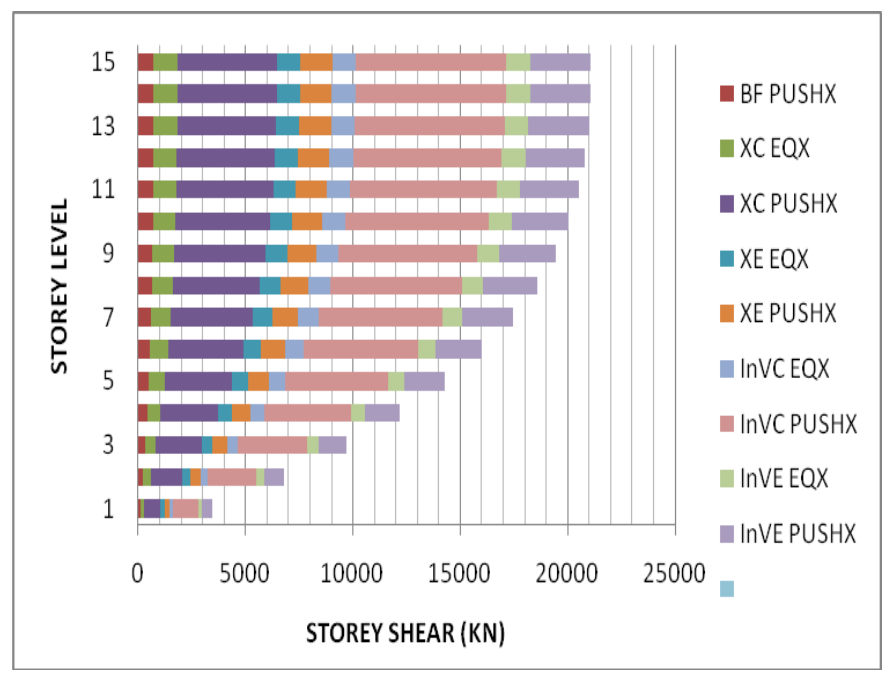

Chart 1: Storey shear for all cosidered models in linear and non-linear static analysis in X-direction.

\subsection{Storey Drift}

Following chart 2 shows storey drift for linear and non linear static analysis in longitudinal $\mathrm{X}$ direction.

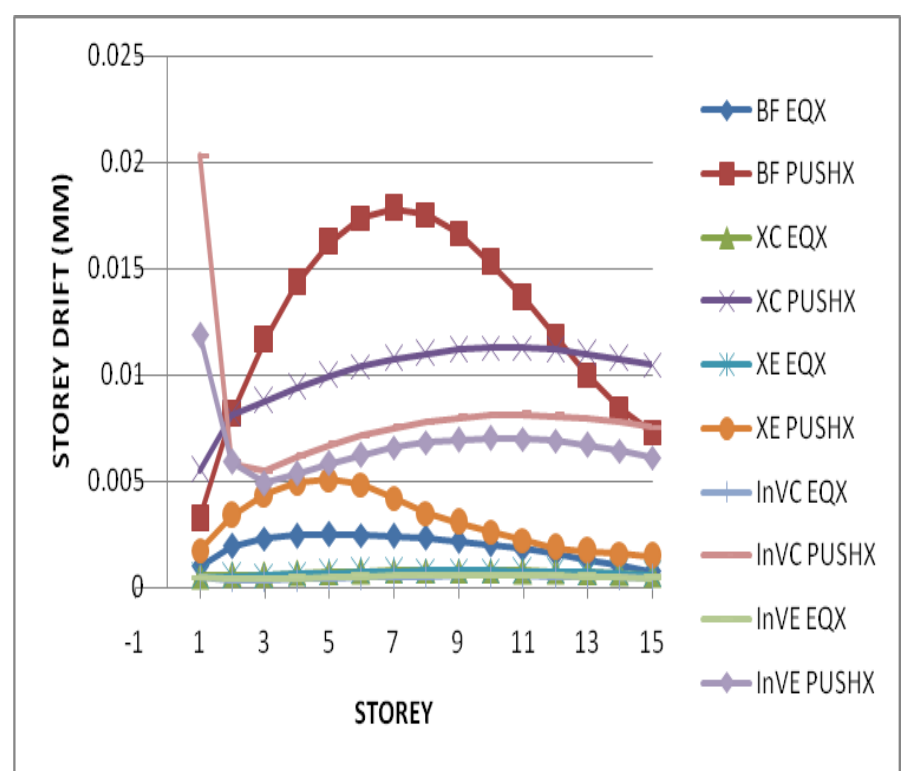

Chart 2: Storey drift for all cosidered models in linear and non-linear static analysis in X-direction.

\subsection{Pushover Curves}

Following figures shows pushover curves for non linear static analysis in $\mathrm{X}$ and $\mathrm{Y}$ direction.

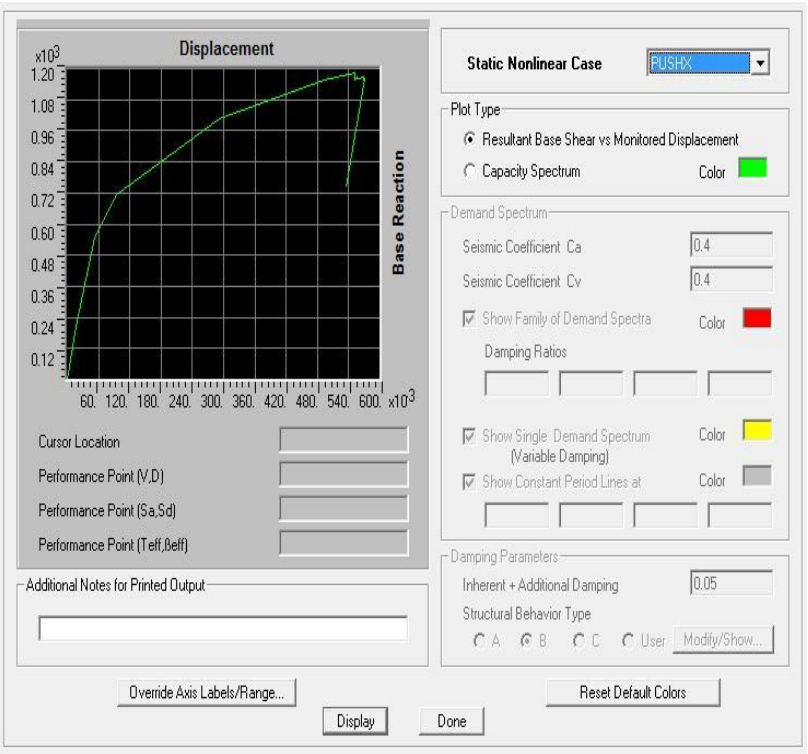

Fig 7: PushX for Bare Frame

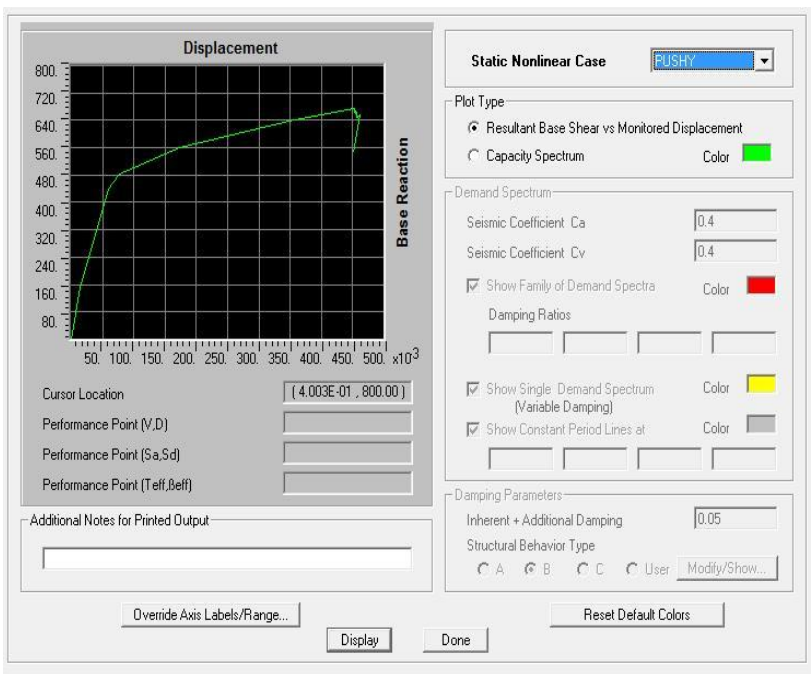

Fig 8: PushY for Bare Frame

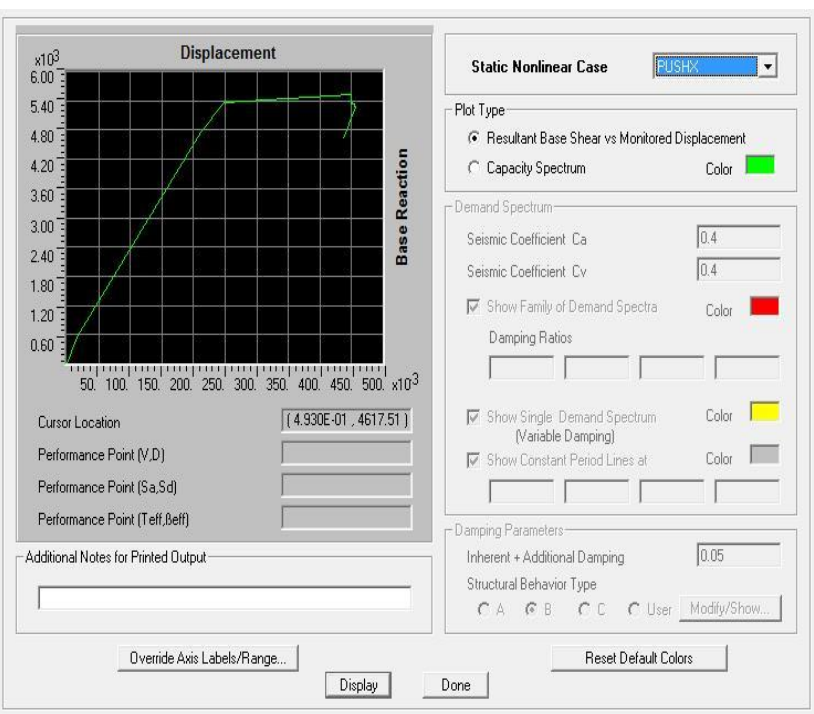

Fig 9: PushX for Concentric X Braced Frame 


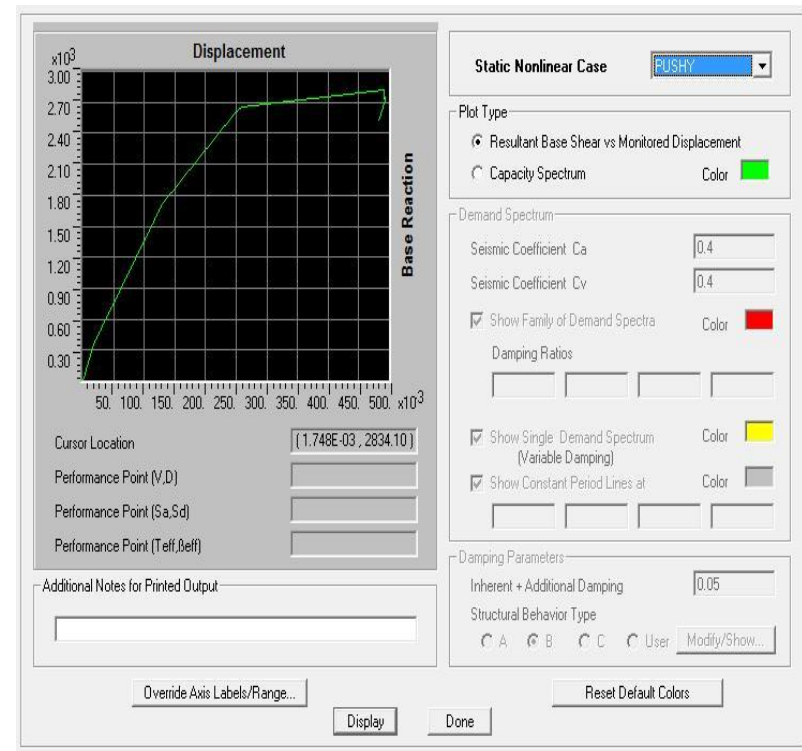

Fig 10: PushY for Concentric X Braced Frame

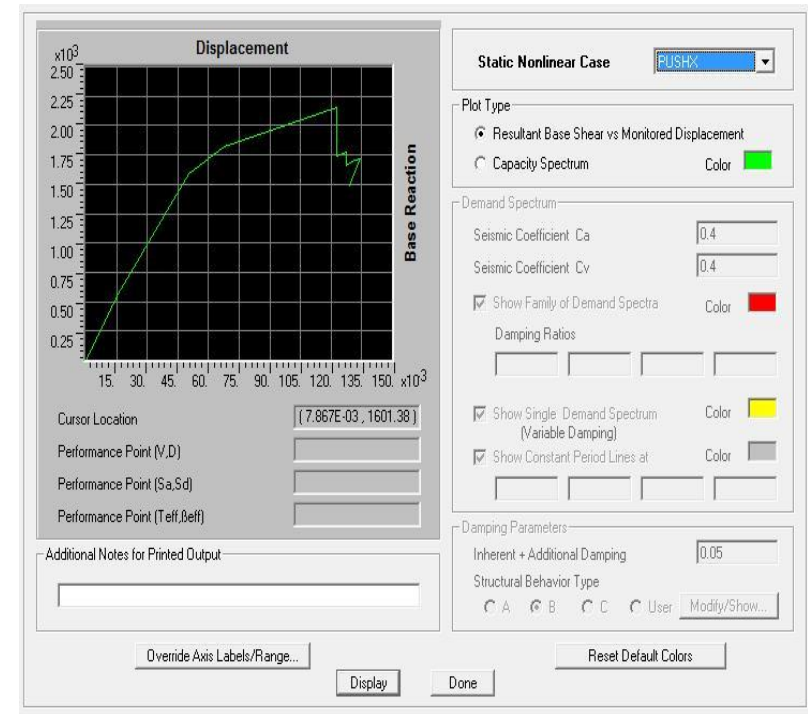

Fig 11: PushX for Eccentric X Braced Frame

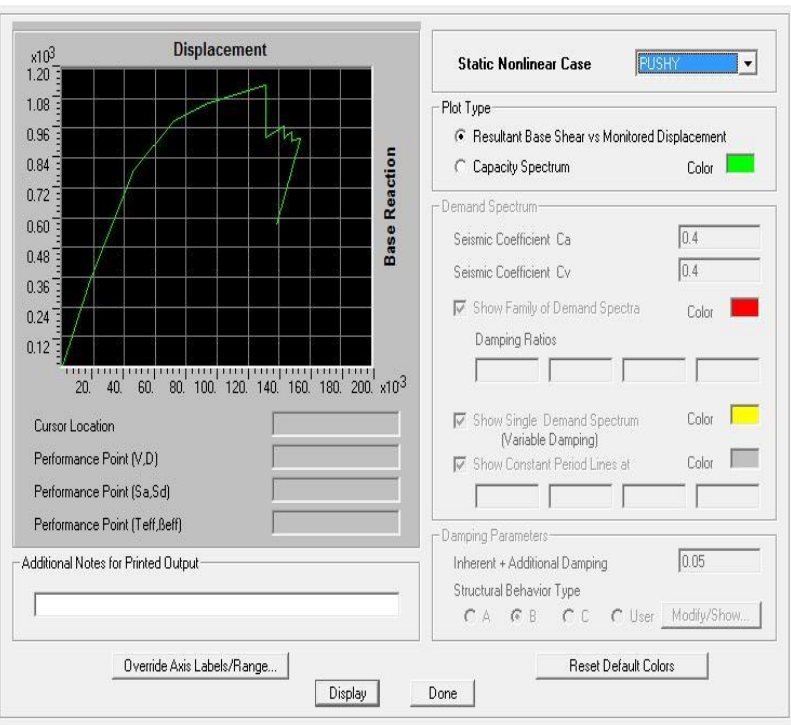

Fig 12: PushY for Eccentric X Braced Frame

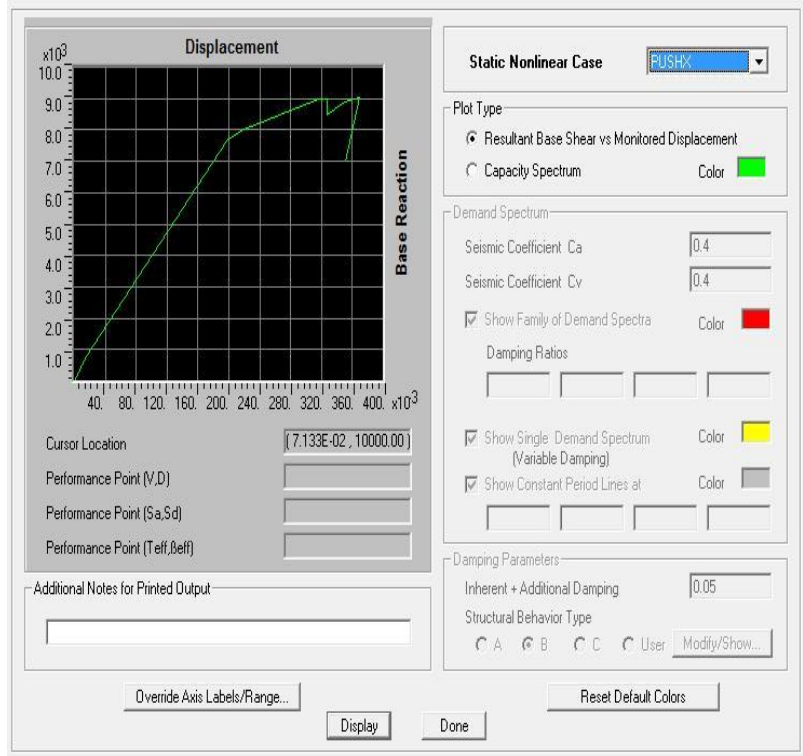

Fig 13: PushX for Concentric Inverted V Braced Frame

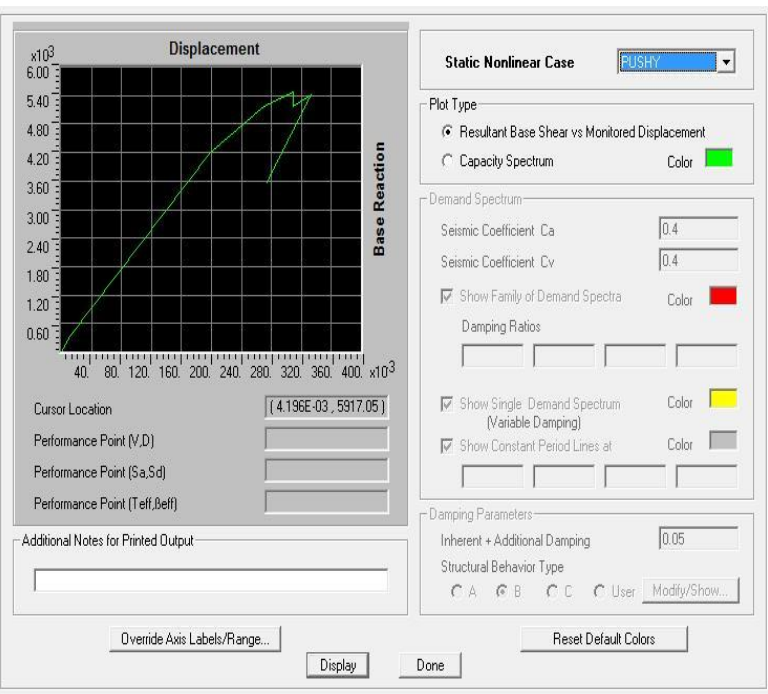

Fig 14: PushY for Concentric Inverted V Braced Frame

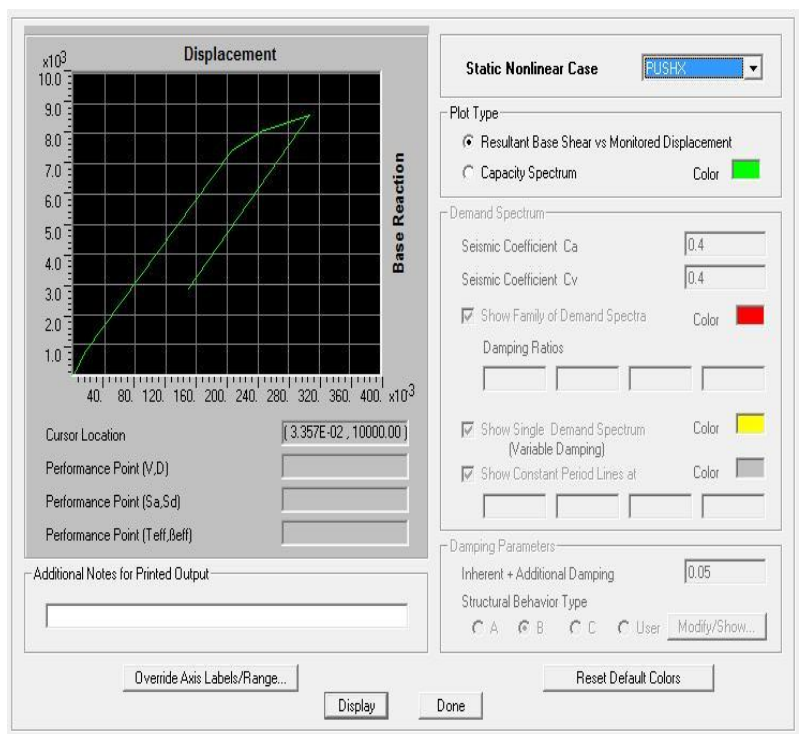

Fig 15: PushX for Eccentric Inverted V Braced Frame 


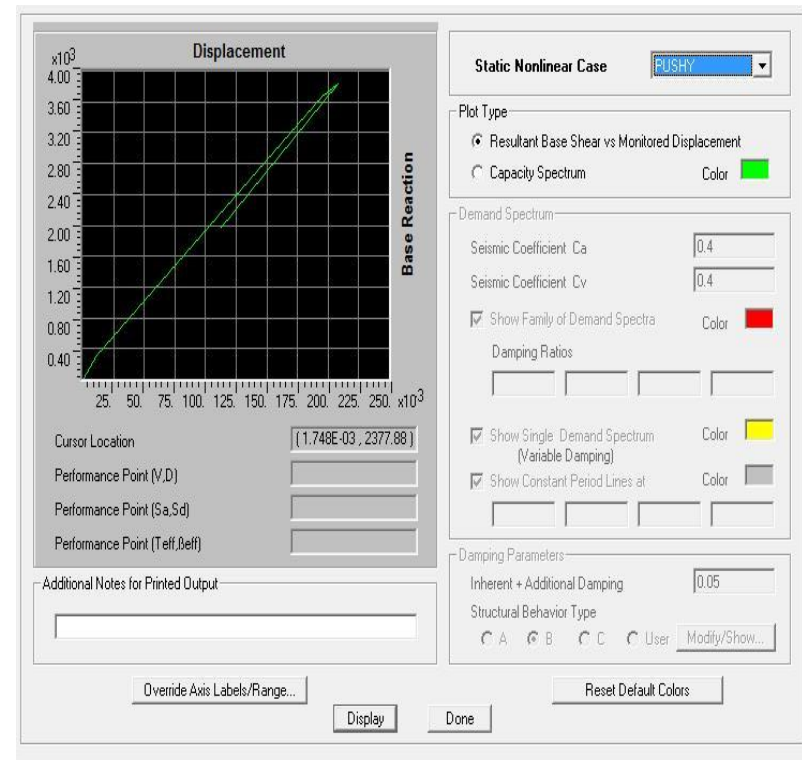

Fig 16: PushY for Eccentric Inverted V Braced Frame

\section{CONCLUSION}

i. From the above results when storey drifts were compared the model with $\mathrm{X}$ bracing was found to give better results for linear static analysis direction when compared to other models.

ii. Also, model with $\mathrm{X}$ bracing was found to give better storey drifts for Pushover i.e non-linear static analysis.

iii. Overall the model with $\mathrm{X}$ bracing is better for both linear and non-linear static analysis.

iv. Also the concentric inverted $\mathrm{V}$ braced model gave better values for storey drifts when compared to other models rendering it to be better than rest of the models.

\section{REFRENCES}

[1] Z.A. Siddiqi, Rashid Hameed and Usman Akmal (2014), "Comparison of different bracing systems for Tall buildings".

[2] en.wikipedia.org/wiki/Braced_frame

[3] NEHRP: Seismic Design Technical Brief No. 8, Seismic Design of Steel Special Concentrically Braced Frame Systems

[4] Hussain Imran K.M and Mrs. Sowjanya G.V (2014), "Stability Analysis of Rigid Steel Frames With and Without Bracing Systems under the Effect of Seismic and Wind Loads".

[5] Vaseem Inamdar and Arun Kumar (2014), "Pushover Analysis of Complex Steel Frame with Bracing Using Etabs".

[6] Vani Prasad and Nivin Philip (2014), "Effectiveness of inclusion of Steel bracing in existing RC framed structure".

[7] Egor P. Popov and Michael D. Engelhardt (1988), "Seismic eccentrically braced frames".

[8] M.Tech Thesis, Kashif, "Comparitive study on Shear wall and Masonry Infill with Mass and Stiffness Irregularities in RC frames".
[9] www.architectjaved.com/nonlinear-staticpushover-analysis/

[10] IS: 1893-2002 (part 1), "Indian Standard Criteria for Earthquake Resistant Design of Structures", fifth revision, Bureau of Indian Standards, New Delhi.

\section{BIOGRAPHIES}

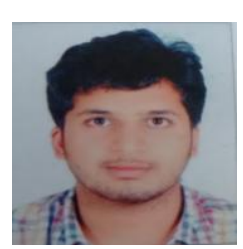

M.Tech Student of Structural Engineering, Department of Civil Engineering, Ghousia College of Engineering, Karnataka, India

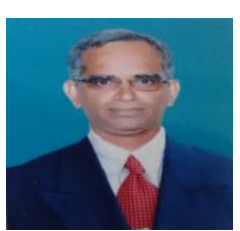

Assistant Professor, Department of Civil Engineering, Ghousia College of Engineering, Karnataka, India

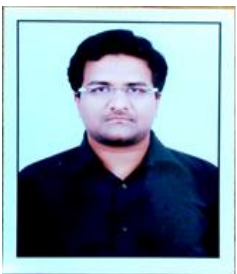

Assistant Professor, Department of Civil Engineering, Ghousia College of Engineering, Karnataka, India 